\title{
"Creative accounting and its influence on corporate performance and financial reporting: A case study of Kosovo"
}

\begin{tabular}{ll} 
AUTHORS & $\begin{array}{l}\text { Enis Abdurrahmani (iD } \\
\text { Zeki Doğan (iD }\end{array}$ \\
& $\begin{array}{l}\text { Enis Abdurrahmani and Zeki Doğan (2021). Creative accounting and its } \\
\text { influence on corporate performance and financial reporting: A case study of } \\
\text { Kosovo. Problems and Perspectives in Management, 19(4), 385-394. } \\
\text { doi:10.21511/ppm.19(4).2021.31 }\end{array}$ \\
\hline ARTICLE INFO & http://dx.doi.org/10.21511/ppm.19(4).2021.31 \\
\hline DOI & Tuesday, 14 December 2021 \\
\hline RELEASED ON & Wednesday, 13 October 2021 \\
\hline RECEIVED ON & Wednesday, 24 November 2021 \\
\hline ACCEPTED ON & $\begin{array}{l}\text { (co) EY } \\
\text { This work is licensed under a Creative Commons Attribution 4.0 International }\end{array}$ \\
\hline LICENSE & License \\
\hline JOURNAL & "Problems and Perspectives in Management" \\
\hline ISSN PRINT & $1727-7051$ \\
\hline ISSN ONLINE & $1810-5467$ \\
\hline PUBLISHER & LLC “Consulting Publishing Company "Business Perspectives" \\
\hline FOUNDER & LLC “Consulting Publishing Company "Business Perspectives"
\end{tabular}

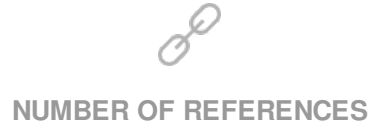

49

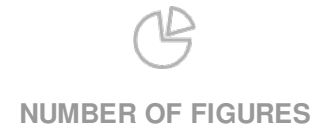

1
NUMBER OF TABLES

6

(C) The author(s) 2021. This publication is an open access article. 


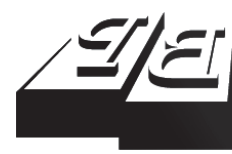

BUSINESS PERSPECTIVES

(O)

LLC "CPC "Business Perspectives"

Hryhorii Skovoroda lane, 10,

Sumy, 40022, Ukraine

www.businessperspectives.org

Received on: $13^{\text {th }}$ of October, 2021 Accepted on: $24^{\text {th }}$ of November, 2021 Published on: $14^{\text {th }}$ of December, 2021

() Enis Abdurrahmani, Zeki Doğan, 2021

Enis Abdurrahmani, Ph.D., Professor, Department of Management, Business and Economics, University for Business and Technology (UBT), Kosovo. (Corresponding author)

Zeki Doğan, Ph.D., Professor, Department of Business Administration, Niğde Ömer Halisdemir University, Turkey.
This is an Open Access article distributed under the terms of the Creative Commons Attribution 4.0 International license, which permits unrestricted re-use, distribution, and reproduction in any medium, provided the original work is properly cited.

Conflict of interest statement: Author(s) reported no conflict of interest

Enis Abdurrahmani (Kosovo), Zeki Doğan (Turkey)

\title{
CREATIVE ACCOUNTING AND ITS INFLUENCE ON CORPORATE PERFORMANCE AND FINANCIAL REPORTING: A CASE STUDY OF KOSOVO
}

\begin{abstract}
As it is known, Kosovo is a newly established and developing country. Naturally, creative accounting practices in Kosovo are becoming more frequent due to gaps and weaknesses in management and audit quality. This study aims to examine the relationship between creative accounting and corporate performance and management, as well as the impact of managers' ethics including audit period on financial reporting and creative accounting limitation. The study adopted a survey-based approach. The questionnaires were distributed among 159 managers, auditors, and head accountants. Linear regression was used to analyze the hypotheses. The research results confirmed the rejection of the first hypothesis, as the mean is less than 3 (the average on a fivepoint Likert scale). The results confirmed that creative accounting has a significant impact on corporate performance. The results also confirmed the second hypothesis as the mean is greater than 3.5 (the average on a five-point Likert scale). Thus, managers' ethics have a significant effect on the reliability of financial statements. In addition, the research results confirmed the acceptance of the third hypothesis, as the mean is greater than 3 (the average on a five-point Likert scale), thus there is a positive influence of the audit period on creative accounting limitation. The study found a negative impact of creative accounting on corporate performance. Furthermore, a significant effect of managers' ethics on financial statements' reliability was concluded; and finally, the findings concluded that audit period and quality could significantly contribute to the creative accounting limitation.
\end{abstract}

Keywords

JEL Classification

\section{INTRODUCTION}

Corporate performance is influenced by the social, economic, and legal regulations of a country. This environment is affected by a high number of risks, which should be recognized and kept under control. The practice of creative accounting is threatening both corporate performance and organizational behavior. The phenomenon of creative accounting is painted as an action that portrays manipulating financial figures, fabrication of financial figures, or even fraud. The expression 'creative accounting' is defined by income smoothing, earnings management, earnings smoothing, financial engineering, and cosmetic accounting. Creative accounting practice works through techniques that are used to interpret the accounting policies desirably to benefit from the loopholes of accounting standards set by accounting bodies. There are many methods of doing it. The most popular ones are the big bath method, cookie jar reserves, manipulation of inventory, principle of materiality, revenue recognition, aggressive amortization, and bad debts overvaluation. 
The review of financial literature shows that creative accounting can be depicted in several ways. Most of the definitions are without substantial differences. The most frequently used notion in the economic literature portrays creative accounting as a technique practiced through accounting rules and principles to deviate from the real and objective presentation of financial figures (Copeland, 1968; Barnea et al., 1976; Amat et al., 1999).

The theoretical and empirical analysis of creative accounting has been the subject of numerous discussions in the financial literature (Hepworth, 1953; Amat et al., 1999; Balaciu et al., 2009; Ramadan, 2017; Hołda \& Staszel, 2016; Tamagno et al., 2017). After major accounting scandals, which have resulted in huge investment losses, several articles assessed the relationship of creative accounting with corporate governance and financial reporting (Hutchinson et al., 2008; Vladu \& Matiş, 2010; Sorin et al., 2012; Haouam \& Feddaoui, 2013; Umobong \& Ironkwe, 2017; Odo \& Ugwu, 2020). Even though there is a limited amount of publications on the correlation between creative accounting and corporate governance, there is also a lack of available contribution on creative accounting influence on corporate performance and management. Consequently, this study tries to fill this gap. So far, there are no similar researches on this topic; this study highlights the influence of creative accounting practice on corporate performance and management, and the effects of managers' ethics and audit period on financial reporting and creative accounting limitation.

\section{LITERATURE REVIEW AND HYPOTHESES}

The conceptual framework drafted by the International Accounting Standards Board is the framework on which all IASs are based. It is the framework that enables management to choose the application of different accounting policies. This flexibility in choosing accounting policies is also the reason for the introduction of creative accounting, which is not always treated as an abusive character.

The origin of the word 'creative' is derived from the Latin word 'creatus', which means 'to grow up'. This word is interpreted as a creative process that means making the original ideas or concepts without deceptive acts (Lukman \& Irisha, 2020). From an early age, Luca Paciolo in his book De Arithmetica gave the first signs of practice of creative accounting. Venetian merchants at the time recorded transactions by keeping double-entry books with ink and pen in the main and auxiliary books. If any discrepancies arose, they would change these books from time to time to make them inadmissible. This example shows that the manipulative behavior of traders is a phenomenon that dates back centuries ago (Susmuş \& Demirhan, 2013).

Creative accounting techniques have become popular since the 1980s. In the last decade, the effects of creative accounting are found in financial scandals of large companies. Bankruptcies of famous companies like Enron, WorldCom, Xerox, and A Hold Royal, etc., exposed the ability of accountants to manipulate financial figures that resulted in misinterpretation of financial information (Shawar \& Qaisar, 2015). Depending on the region where it is practiced, creative accounting can be treated as a positive or negative perception. According to Hołda and Staszel (2016), creative accounting can be understood as a positive (in Central and Eastern Europe), a negative (mostly in German and English-speaking countries), or a neutral occurrence (in South America).

The theoretical and empirical background of creative accounting is examined in different aspects. This review is anchored to empirical reviews regarding the motives, ethics, and influence of creative accounting on corporate performance, audit period, and audit quality. Research findings from the literature pointed out the motives and effects of creative accounting. These findings are useful for this study, as they identify different effects of creative accounting and provide adequate evaluation methods.

Amat et al. (1999) and Cugova and Cug (2020) highlighted that there is a broad diversity of managers' motivation for creative accounting. The most significant of which are achieving zero risks 
related to the sale of used assets, favorable credits, loan extensions, easier access to financing, meeting the expectations of owners, banks, and creditors, increasing the value of a company when it is sold, merged, or bought, financial risks concealment and consolidation of a company's place in the market.

Ali et al. (2020) argued that income smoothing affects the financial performance of public firms. Moreover, Amat et al. (1999) argued that income smoothing is profit manipulation related to forecasting, and creative accounting can be used to keep the stock prices and report profit growth.

Furthermore, Okoye and Obioma (2020) described the correlation between creative accounting techniques and the financial performance of companies. It was concluded that asset structure and equity capital have a negative and insignificant effect on the return on assets while loans are positively and insignificantly related to the returns on assets. In addition, Qatawneh and Alqtish (2017) confirmed a positive impact of ethics and creative accounting on financial statements. Ismael (2017) proved a negative effect of creative accounting on financial reporting reliability. On the other hand, Mârza et al. (2017) stated that creative accounting is considered legal even though it tends to change the real image and is associated with deception.

Siyanbola et al. (2020) investigated the influence of creative accounting on investment decisions. It was found that creative accounting positively but insignificantly affects investments. There are positive effects and benefits in terms of profit management, which directly depend on the current motivation of management. Effiok and Eton (2012) carried out similar research on the impact of creative accounting on management decisions. They confirm that creative accounting affects the price of firms and capital market performance.

On the ethical issues of creative accounting, Amat and Gowthorpe (2004) and Gabriels and Wiele (2005) argue that ethical standards and codes of governance should be implemented with discipline in corporate governance. On the other line, Ismael (2017) investigated the relationship between creative accounting, ethics, and financial reporting. It was proved that creative accounting has a negative impact on the reliability of financial reporting.

Furthermore, modern literature investigated correlations between creative accounting and audit. The primary role of an auditor is to clarify professionally and reasonably whether financial statements prepared by the companies provide objective and reliable information. Audit quality increases financial reporting quality by improving investors' confidence (Hasan et al., 2020). In addition, audit quality may mitigate problems appearing from information asymmetry (Dobler, 2008). Lei (2009) examined the influence of creative accounting on risks associated with the audit. It was shown that creative accounting affects audit risks and investment losses. Hamdan et al. (2013) found that audit quality does not affect operating performance but influences earnings smoothing and stock performance. On the other line, Teitel and Machuaga (2009) argued that high-quality auditors could significantly influence earnings improvements. Furthermore, Hasan et al. (2020) explored the effect of the audit committee and audit quality on earning management restrictions. It was revealed that audit committee and audit quality significantly affect restrictions in the real earning management. On the contrary, Ching et al. (2015) revealed that audit quality does not limit earnings management and does not influence the quality of financial reporting.

The study also reviewed the limited literature on theoretical frameworks based on agency theory, signaling theory, and shareholder theory. The agency problem is one of the age-old problems that have progressed since the expansion of the joint-stock companies (Panda \& Leepsa, 2017). Ross (1973) identified the principal and agent problem as a result of the reward compensation decision. An inappropriate reward compensation package may motivate managers to use the owners' property for their self-interest. Managers are more focused on their return maximization. Therefore, the agency theory may affect creative accounting because of the self-interest conflicts of both the principal and the agent (Ali et al., 2020). However, the relationship of corporate performance with creative accounting practice may occur when managers try to report increased profits to maximize their interest instead of owners' interest. 
Signaling theory is a concept where a signaler credibly conveys some signal about itself to the receiver. In financial literature, signalers are employees or managers (Hochwater et al., 2007; Ramaswami et al., 2010); receivers are generally investors or shareholders (Park \& Mezias, 2005; Daily et al., 2005; Busenitz et al., 2005). According to Spence (1973), signaling influences job options in the market. Connelly et al. (2011) researched corporate governance and described how CEOs tell about the indiscernible quality of their firms to possible investors due to the apparent quality of financial statements. This theory focuses on solving the issue of information asymmetry within a competitive environment (Bae et al., 2018). The signal reduces the possibility of information asymmetry and avoids potential conflicts between management and shareholders.

Shareholder theory is a theory of business ethics elaborated by Friedman (1970), which confirms that a company is uniquely and solely responsible before its shareholders (Smith, 2003). This theory explains that firms are not obligated to seek anything other than profit maximization. The focus must be only on profit maximization without any social and public responsibility. According to Bankole et al. (2018), shareholder theory confirms the idea that managers prepare financial statements following the demands and interests of shareholders, employees, government agencies, etc. This way, they can be pressured to alter financial figures to change the perception of a particular group of parties. Given this theory, a conflict of interests, which arises between shareholders' main goal of profit maximization and managers' persistence to increase the company's profit, may influence creative accounting practice.

To conclude, the majority of existing studies have been focused on mixed dimensions of correlations among creative accounting, audit quality, and financial reporting. This study intends to cover this gap in the existing literature by testing the creative accounting implication on corporate performance, and effects of managers' ethics and audit period on financial reporting. Moreover, the study highlights the importance of creative accounting in small countries like Kosovo that are going through a transition environment. Therefore, this paper aims to assess the influence of creative ac- counting practices on corporate performance, management, and financial statements' reliability. As a result, the present study tests the validity of the following three hypotheses:

\section{$H_{1}$ : A creative accounting practice insignificantly influences corporate performance.}

$\mathrm{H}_{2}$ : Managers' ethics significantly effects the reliability of financial statements.

$\mathrm{H}_{3}$ : The audit period positively influences the limitation of creative accounting.

\section{METHODOLOGY}

This study adopts a survey research method. Data were obtained using questionnaires containing 21 structured questions. The population of this study was certified auditors, certified accountants, and company managers from different cities of the country. Questions are randomized on a block basis, so all questions appear in the same block of questions. The paper adopts the model developed by Abdurrahmani and Doğan (2019) to determine the amount of samples for the survey:

$$
n=\frac{x \cdot(1-x)}{[S \cdot E(p)]^{2}},
$$

where $n=$ the number of samples; $X=$ variability; $[S . E(p)]=$ Std. error.

Based on this, 159 respondents were selected through a random sampling technique. Valid samples to the process were 150 from 159 samples. SPSS 26 (Statistical Package for Social Sciences) was used as an application for data analysis and hypothesis testing. Statistic T-test was adopted at a 5\% level of significance. Questionnaire answers were measured based on the 5-point Likert scale.

\section{RESULTS}

Currently, in the Republic of Kosovo, there are 720 active certified accountants and 83 certified auditors (KKRF, 2021). The demographic structure of the respondents participating in the survey is presented in Figure 1. 


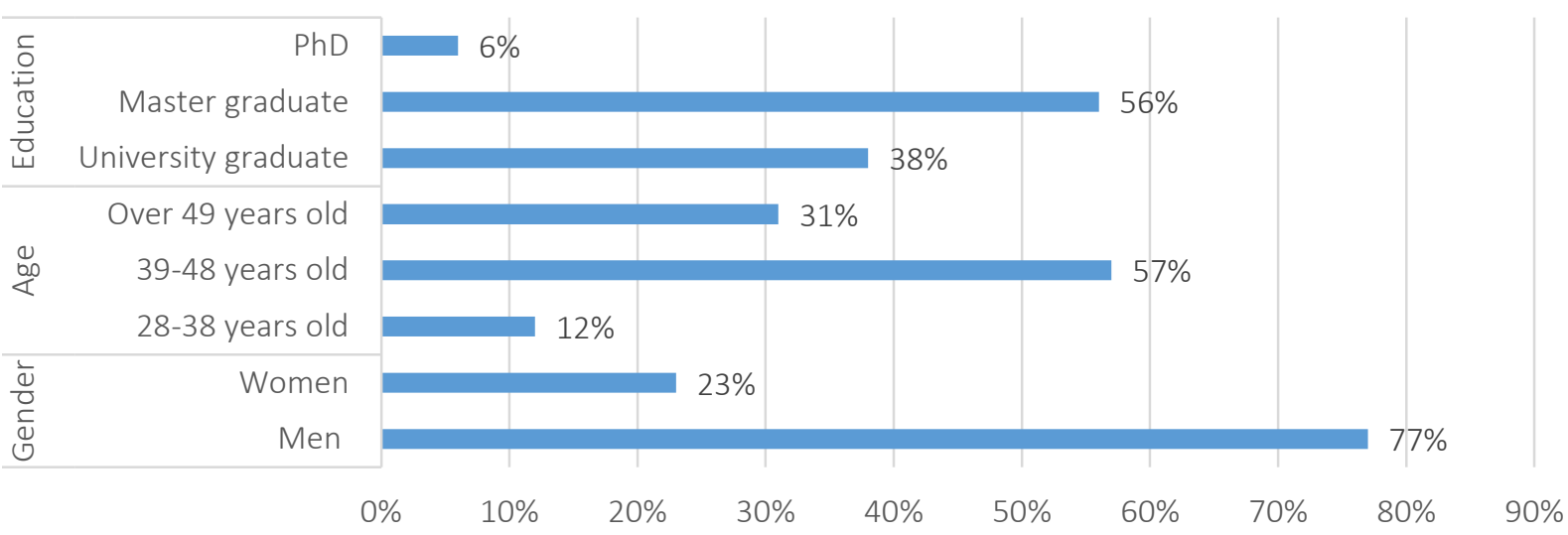

Figure 1. Demographic characteristics of respondents

As seen in Figure 1,77\% of the respondents were men and $23 \%$ were women, $12 \%$ of the respondents were aged from 28 to 38 years, $57 \%$ of the respondents were from 39 to 48 years old and $31 \%$ of the respondents were over 49 years old. While in terms of education, $38 \%$ of the respondents were university graduates, $56 \%$ of the respondents were master graduates, and $6 \%$ of the respondents were PhDs.

\subsection{Descriptive statistics}

Table 1 illustrates the descriptive statistics. It is shown that $18.7 \%$ of the respondents strongly agree whereas $20.7 \%$ agree that creative accounting does not affect corporate performance. In addition, $12 \%$ were neutral and $26.0 \%$ disagree while
$22.7 \%$ strongly disagree that creative accounting does not affect corporate performance. Since the mean is less than 3 , the results reject the hypothesis of the insignificant influence of creative accounting on corporate performance and support the statement that creative accounting significantly affects corporate performance.

According to the result of descriptive analysis, as shown in Table 2, $32.7 \%$ of the respondents strongly agree while $26.7 \%$ agree that managers' ethics have a significant effect on financial statements. Whereas $13.3 \%$ were neutral and $15.3 \%$ disagree while $12.0 \%$ strongly disagree that managers' ethics have a significant effect on financial statements. Since the mean is greater than 3.5 , it is accepted

Table 1. Descriptive statistics on the influence of creative accounting on corporate performance

\begin{tabular}{|c|c|c|c|c|c|c|c|c|}
\hline \multirow{2}{*}{ Groups } & \multirow{2}{*}{ Count } & \multicolumn{5}{|c|}{ Creative accounting effects } & \multicolumn{2}{|c|}{ Statistics } \\
\hline & & Strongly agree & Agree & Neutral & Disagree & Strongly disagree & Mean & d. deviation \\
\hline Auditor & 56 & 12 & 13 & 4 & 14 & 13 & \multirow{5}{*}{2.87} & \multirow{5}{*}{1.455} \\
\hline Accountant & 59 & 9 & 14 & 6 & 16 & 14 & & \\
\hline Manager & 35 & 7 & 4 & 8 & 9 & 7 & & \\
\hline Total & 150 & 28 & 31 & 18 & 39 & 34 & & \\
\hline$\%$ of total & $100.0 \%$ & $18.70 \%$ & $20.70 \%$ & $12.00 \%$ & $26.00 \%$ & $22.70 \%$ & & \\
\hline
\end{tabular}

Table 2. Descriptive statistics on the effects of managers' ethics on financial statements' reliability

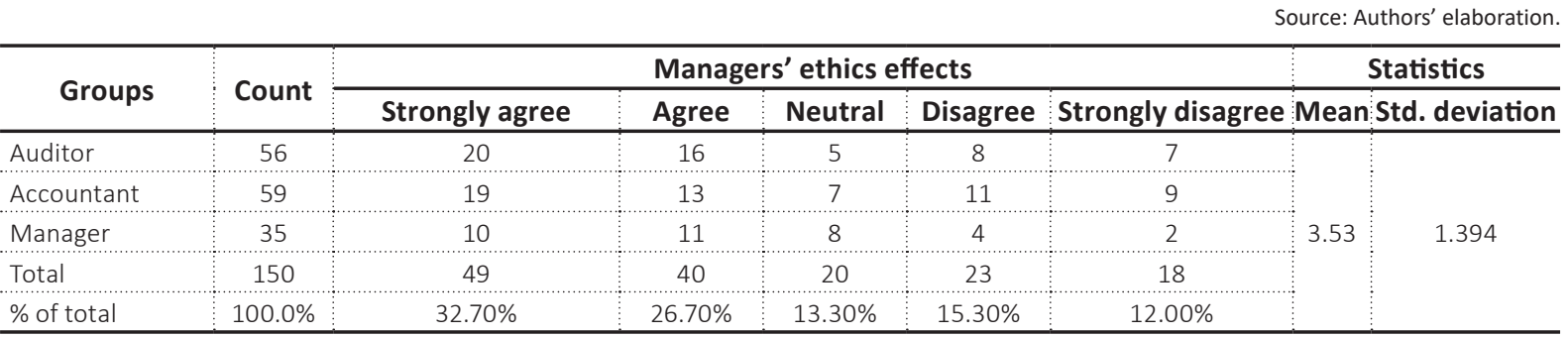


Table 3. Descriptive statistics on the influence of audit period on creative accounting

\begin{tabular}{|c|c|c|c|c|c|c|c|c|}
\hline \multirow{2}{*}{ Groups } & \multirow{2}{*}{ Count } & \multicolumn{5}{|c|}{ Audit period effects } & \multirow{2}{*}{\multicolumn{2}{|c|}{\begin{tabular}{|c|} 
Statistics \\
Mean Std. deviation
\end{tabular}}} \\
\hline & & Strongly agree & Agree & Neutral & Disagree & Strongly disagree & & \\
\hline Auditor & 56 & 21 & 14 & 6 & 9 & 6 & \multirow{5}{*}{3.3} & \multirow{5}{*}{1.4} \\
\hline Accountant & 59 & 13 & 9 & 3 & 18 & 16 & & \\
\hline Manager & 35 & 9 & 15 & 5 & 4 & 2 & & \\
\hline Total & 150 & 43 & 38 & 14 & 31 & 24 & & \\
\hline$\%$ of total & $100.0 \%$ & $28.70 \%$ & $25.30 \%$ & $9.30 \%$ & $20.70 \%$ & $16.00 \%$ & & \\
\hline
\end{tabular}

that managers' ethics significantly effects financial statements' reliability.

As shown from descriptive analysis in Table 3, 28.7\% of the respondents strongly agree whereas $25.3 \%$ agree that the audit period positively affects creative accounting limitations. In addition, 9.3\% were neutral and $20.7 \%$ disagree while $16.0 \%$ strongly disagree that the audit period positively affects creative accounting limitation. Since the mean is greater than 3 , it is accepted that the audit period positively affects the limitation of creative accounting.

\subsection{Hypotheses testing}

The hypothesis testing is done using linear regression. Table 4 illustrates linear regression analysis results for the first hypothesis. This analysis assesses the influence of creative accounting prac- tice on corporate performance. Creative accounting practice is the independent variable, while the dependent variable is corporate performance.

As shown in Table 4, correlation results show a negative significant correlation $(-0.946)$ between creative accounting practice and corporate performance. The regression results indicate that $89.6 \%$ of variation in corporate performance was interpreted by creative accounting $(t=12.683, \beta=-0.946, R 2=0.896, P=$ $0.000 ; P<0.05)$. Hence, the study result rejects the null hypothesis that claims the insignificant effect of creative accounting on corporate performance and supports the alternative hypothesis: creative accounting negatively affects corporate performance.

Table 5 shows the results of linear regression analysis for $H_{2}$. The aim is to assess the impact of managers' ethics on financial statements' reliability. The

Table 4. Linear regression analysis for $H_{1}$

\begin{tabular}{|c|c|c|c|c|c|c|c|c|c|}
\hline \multicolumn{10}{|c|}{ source: Autnors elavoration } \\
\hline Independent variable & \multicolumn{7}{|c|}{ Dependent variable (Corporate performance) } & $\begin{array}{c}\text { Pearson } \\
\text { correlation }\end{array}$ & Model \\
\hline \multirow{2}{*}{ Creative accounting } & $\beta$ & $t$-value & Sig. & $\mathbf{F}$ & B & Mean & Std. deviation & & \\
\hline & -0.946 & 61.406 & .000 & 12.683 & 6.174 & 2.87 & 1.45 & -0.946 & - \\
\hline$R$ & - & - & - & - & - & - & - & - & $.946^{\mathrm{a}}$ \\
\hline$R^{2}$ & - & - & - & - & - & - & - & - & .896 \\
\hline$\Delta R^{2}$ & - & - & - & - & - & - & - & - & .895 \\
\hline ANOVA (sig.) & - & - & - & - & - & - & - & - & $.000^{\mathrm{b}}$ \\
\hline
\end{tabular}

Note: ${ }^{a}$ Respondent (predictors) constant interaction; ${ }^{b}$ Overall interaction with corporate performance.

Table 5. Linear regression analysis for $H_{2}$

\begin{tabular}{|c|c|c|c|c|c|c|c|c|c|}
\hline \multirow{3}{*}{$\begin{array}{c}\text { Independent variable } \\
\text { Managers' ethics }\end{array}$} & \multicolumn{7}{|c|}{ Dependent variable (Financial statements' reliability) } & \multirow{2}{*}{$\begin{array}{c}\text { Pearson } \\
\text { correlation }\end{array}$} & \multirow{2}{*}{ Model } \\
\hline & $\beta$ & $t$-value & sig. & $\mathbf{F}$ & B & Mean & Std. deviation & & \\
\hline & .898 & 24.809 & .000 & 61.546 & 3.681 & 3.53 & 1.394 & .898 & - \\
\hline $\mathrm{R}$ & - & - & - & - & - & - & - & - & $.898^{\mathrm{a}}$ \\
\hline $\mathrm{R}^{2}$ & - & - & - & - & - & - & - & - & .806 \\
\hline$\Delta R^{2}$ & - & - & - & - & - & - & - & - & .805 \\
\hline ANOVA (sig.) & - & - & - & - & - & - & - & - & $.000^{\mathrm{b}}$ \\
\hline
\end{tabular}

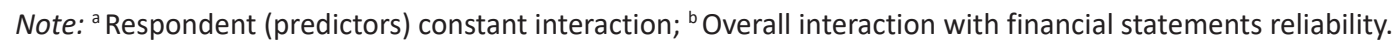


Table 6. Linear regression analysis for $H_{3}$

\begin{tabular}{|c|c|c|c|c|c|c|c|c|c|}
\hline \multicolumn{10}{|c|}{ Source: Authors' elaboration. } \\
\hline Independent variable & \multicolumn{7}{|c|}{ Dependent variable (Limitation of creative accounting) } & \multirow{2}{*}{$\begin{array}{l}\text { Pearson } \\
\text { correlation }\end{array}$} & \multirow{2}{*}{ Model } \\
\hline \multirow{2}{*}{ Audit period } & $\beta$ & t-value & sig. & $\mathbf{F}$ & B & Mean & Std. deviation & & \\
\hline & 0.925 & 16.406 & 0.000 & 87.436 & 4.253 & 3.30 & 1.418 & 0.925 & \\
\hline$R$ & - & - & - & - & - & - & - & - & $.925^{\mathrm{a}}$ \\
\hline$R^{2}$ & - & - & - & - & - & - & - & - & .855 \\
\hline$\Delta R^{2}$ & - & - & - & - & - & - & - & - & .854 \\
\hline ANOVA (sig.) & - & - & - & - & - & - & - & - & $.000^{\mathrm{b}}$ \\
\hline
\end{tabular}

Note: ${ }^{a}$ Respondent (predictors) constant interaction; ${ }^{b}$ Overall interaction with creative accounting limitation.

independent variable is managers' ethics, and the dependent variable is financial statements' reliability.

As shown in Table 5, correlation results show a positive significant correlation (0.898) between managers' ethics and financial statements' reliability. The regression results indicate that $80.6 \%$ of variation in financial statements reliability was interpreted by managers' ethics $(t=24.809, \beta=0.898, R 2=0.806, P$ $=0.000 ; P<0.05)$. Therefore, the second hypothesis is accepted. Hence, it is concluded that as managers' ethics improves, financial statements' reliability will also increase.

Table 6 provides linear regression analysis results for $\mathrm{H}_{3}$ to assess the influence of the audit period on the limitation of creative accounting practice. The independent variable is the audit period, and the dependent variable is the creative accounting limitation.

As shown in Table 6, the correlation results revealed a positive significant relationship (0.925) between the audit period and creative accounting limitation. The regression results indicate that $85.5 \%$ of variation in creative accounting limitation was interpreted by audit period $(t=16.406, \beta=0.925, R 2=0.855, P=0.000$; $P<0.05)$. Therefore, the third hypothesis is accepted. Hence, it is concluded that as the audit period increases, creative accounting practice will reduce.

\section{DISCUSSION}

This study examined the impact of creative accounting on corporate performance and the influence of managers' ethics, including audit period, on financial reporting and creative accounting limitation. Based on the background, the research results of this paper revealed a negative impact of creative accounting on corporate performance whereas the correlation analysis shows a significant negative relationship between creative accounting and corporate performance. This can be interpreted that the frequent practice of creative accounting significantly impairs corporate results and performance. Vice versa, the lower practice of creative accounting can contribute to better corporate performance results. These results are in line with Odo and Ugwu (2020), who found that in Nigeria creative accounting negatively affects bank performance.

In addition, it is shown that the influence of managers' ethics on financial statements is quite significant. Education of managers and contribution to ethical standards can reduce the negative effect of creative accounting. These results can be interpreted as higher ethics of corporate managers will encourage more reliable financial statements. This result complies with Lukman and Irisha (2020), who found a positive significant influence of statutory auditor and ethical standards on financial reporting reliability.

Moreover, it is concluded that the audit period positively affects the limitation of creative accounting practices. Thus, the higher quality and period of audit can contribute to the reduction of creative accounting practice. These results confirm Ogoun and Atagboro (2020), who found that internal audit influences the level of creative accounting practices.

\section{CONCLUSION}

The study aimed to estimate the impact of creative accounting on corporate performance and the influence of managers' ethics and audit period on financial reporting and creative accounting practice. 
The findings revealed that creative accounting significantly aggravates corporate performance. Furthermore, the results suggested that the influence of managers' ethics on financial statements is quite significant; higher ethics of corporate managers will promote higher reliability of financial statements. The results also showed that audit period and audit quality positively affect the reduction of creative accounting practices.

Following these results and discussions, it is stated that several conclusions can be provided by this study. The research findings conclude that creative accounting negatively influences corporate performance. The frequent practice of creative accounting significantly impairs corporate results and performance. In addition, there is a strong correlation between managers' ethics and creative accounting. As managers' ethics advance, the influence of creative accounting on financial statement reliability shall minimize. Finally, the research finding highlights the role of the audit period on creative accounting. Audit period and quality can significantly contribute to the creative accounting limitation. More frequent audit periods can significantly reduce creative accounting practices.

\section{AUTHOR CONTRIBUTIONS}

Conceptualization: Enis Abdurrahmani, Zeki Doğan.

Data curation: Enis Abdurrahmani.

Formal analysis: Enis Abdurrahmani.

Funding acquisition: Enis Abdurrahmani.

Investigation: Enis Abdurrahmani.

Methodology: Enis Abdurrahmani, Zeki Doğan.

Project administration: Enis Abdurrahmani.

Resources: Enis Abdurrahmani, Zeki Doğan.

Software: Enis Abdurrahmani.

Supervision: Zeki Doğan.

Validation: Enis Abdurrahmani.

Visualization: Zeki Doğan.

Writing - original draft: Enis Abdurrahmani.

Writing - review \& editing: Enis Abdurrahmani, Zeki Doğan.

\section{REFERENCES}

1. Abdurrahmani, E., \& Doğan, Z. (2019). The social, economic and fiscal effects of tax amnesty the evidence from Kosovo. International Journal of Management Excellence, 13(2), 1910-1921. https:// doi.org/10.17722/ijme.v13i2.1099

2. Ali, M. M., Haron, H. N., Othman, A. N., \& Hasnan, S. (2020). Creative accounting and financial performance of public listed companies in Malaysia. Humanities and Social Sciences Letter, 8(1), 12-22. https://doi.org/10.18488/ journal.73.2020.81.12.22

3. Amat, O., \& Gowthorpe, C. (2004). Creative accounting: nature, incidence and ethical issues (UPF Working Paper No. 749). https:// doi.org/10.2139/SSRN.563364
4. Amat, O., Blake, J., \& Dowds, J. (1999). The ethics of creative accounting (Economics Working Papers No. 349). Universitat Pompeu Fabra. Retrieved from https:// econ-papers.upf.edu/papers/349. pdf

5. Bae, S., Masud, M., \& Kim, J. (2018). A cross-country investigation of corporate governance and corporate sustainability disclosure: A signaling theory perspective. Sustainability, 10(8), 2611. https:// doi.org/10.3390/su10082611

6. Balaciu, D., Bogdan, V., \& Vladu, B. A. (2009). A brief review of creative accounting literature and its consequences in practice. Annales Universitatis Apulensis Series Oeconomica, 11(1), 170-183. Retrieved from https://core.ac.uk/download/ pdf/6481349.pdf

7. Bankole, O. K., Ukolobi, O. I., \& McDubus, F. O. (2018). Creative accounting practices and shareholders' wealth. Accounting and Taxation Review, 2(4), 58-74. Retrieved from https://www.atreview.org/admin/12389900798187/ ATR\%202(4)\%2058-74_pdf.pdf

8. Barnea, A., Ronen, J., \& Sadan, S. (1976). Classificatory smoothing of income with extraordinary items. The Accounting Review, 51(1), 110-122. Retrieved from https://www.jstor.org/ stable/245377

9. Busenitz, L. W., Fiet, J. O., \& Moesel, D. D. (2005). Signaling in venture capitalist - new venture 
team funding decisions: Does it indicate long-term venture outcomes? Entrepreneurship Theory and Practice, 29(1), 1-12. https://doi.org/10.1111/j.15406520.2005.00066.x

10. Ching, C. P., Teh, B. H., San, O. T. \& Hoe, H. Y. (2015). The relationship among audit quality, earnings management, and financial performance of Malaysian public listed companies. International Journal of Economics and Management, 9(1), 211-229. Retrieved from http://www.ijem.upm.edu. my/vol9no1/11.\%20The\%20Relationship\%20among\%20Audit\%20 Quality.pdf

11. Connelly, L. B., Certo, T. S., Ireland, D. R., \& Reutzel, R. Ch. (2011). Signaling theory: A review and assessment. Journal of Management, 37(1), 39-67. https://doi. org/10.1177/0149206310388419

12. Copeland, R. M. (1968). Income smoothing. Journal of Accounting Research, 6, 101-116. https://doi. org/10.2307/2490073

13. Cugova, A., \& Cug, J. (2020). Motivation for the use of creative accounting techniques in the conditions of the globalized business environment. SHS Web of Conferences, 74, 01004. http://dx.doi. org/10.1051/shsconf/20207401004

14. Daily, C. M., Certo, S. T., \& Dalton, D. R. (2005). Investment bankers and IPO pricing: Does prospectus information matter? Journal of Business Venturing, 20(1), 93-111. https://doi.org/10.1016/j.jbusvent.2003.10.003

15. Dobler, M. (2008). Incentives for risk reporting - A discretionary disclosure and cheap talk approach. The International Journal of Accounting, 43(2), 184-206. https://doi.org/10.1016/j.intacc.2008.04.005

16. Effiok, S. O., \& Eton, O. E. (2012). Creative Accounting and Managerial Decision on Selected Financial Institutions in Nigeria. International Journal of Business Research and Management, 3(1), 35-47. Retrieved from http:// www.cscjournals.org/manuscript/ Journals/IJBRM/Volume3/Issue1/ IJBRM-61.pdf
17. Friedman, M. (1970, September 13). A Friedman Doctrine: The social responsibility of business is to increase its profits. The New York Times. Retrieved from https:// www.nytimes.com/1970/09/13/ archives/a-friedman-doctrine-thesocial-responsibility-of-businessis-to.html

18. Gabriels, X., \& Wiele, P. V. D. (2005). Creative accounting: ethical perceptions among accounting and non-accounting students (Working Papers No. 2005016). University of Antwerp. Retrieved from https://ideas.repec.org/p/ant/wpaper/2005016.html

19. Hamdan, M. A., Sarea, M. A., \& Reyad, R. S. (2013). The impact of audit committee characteristics on the performance of firms: Evidence from Jordan. International Management Review, 9(1), 32-42. Retrieved from https://www.researchgate.net/ publication/288267526_The_Impact_of_Audit_Committee_Characteristics_on_the_Performance_. Evidence_from_Jordan

20. Haouam, D., \& Feddaoui, A. (2013). Corporate governance and creative accounting. Badji Mokhtar University. Retrieved from http:// iefpedia.com/arab/wp-content/uploads/2013/12/creative-accountingCGovern1.pdf

21. Hasan, Sh., Kassim, A. A., \& Hamid, A. A. M. (2020). The impact of audit quality, audit committee and financial reporting quality: Evidence from Malaysia. International Journal of Economics and Financial Issues, 10(5), 272-281. https://doi.org/10.32479/ ijefi.10136

22. Hepworth, S. R. (1953). Smoothing periodic income. The Accounting Review, 28(1), 32-39. Retrieved from https://www.jstor.org/ stable/241436

23. Hochwater, W. A., Ferris, G. R., Zinko, R., Arnell, B., \& James, M. (2007). Reputation as a moderator of political behavior-work outcomes relationships: A two study investigation with convergent results. Journal of Applied Psychology, 92(2), 567-576. https://doi. org/10.1037/0021-9010.92.2.567
24. Hołda, A., \& Staszel, A. (2016). Definitions, perception and functioning of creative accounting in the theory and practice of different languages, countries and parts of the world. China-USA Business Review, 15(5), 205-225. https://doi.org/10.17265/15371514/2016.05.001

25. Hutchinson, M. R., Percy, M., \& Erkurtoglu, L. (2008). An investigation of the association between corporate governance, earnings management and the effect of governance reforms. Accounting Research Journal, 21(3), 239-262. http://dx.doi. org/10.1108/10309610810922495

26. Ismael, A. Y. A. (2017). The impact of creative accounting techniques on the reliability of financial reporting with particular reference to Saudi auditors and academics. International Journal of Economics and Financial Issues, 7(2), 283-291. Retrieved from https://dergipark.org.tr/en/download/article-file/365715

27. Këshilli Kosovar për Raportim Financiar (KKRF). (2021). Lista e Kontabilistëve të Certifikuar (KC/AC) dhe Auditorëve Ligjor (data e azhurnimit 20.05.2021). (In Albanian). Retrieved from https://mf.rks-gov.net/desk/inc/ media/160F32E8-E758-4829880B-7FB21133AE21.pdf

28. Lei, L. (2009). The audit risk associated with fraudulent accounting of listed companies in China: A case study (Doctoral Thesis). University of Nottingham. Retrieved from https://www.docin. com/p-301950073.html

29. Lukman, H., \& Irisha, Th. (2020). The effect of creative accounting practices with statutory auditor as mediation, and accountant ethics standards on the reliability of financial statements. Proceedings of the $2^{\text {nd }}$ Tarumanagara International Conference on the Applications of Social Sciences and Humanities (TICASH 2020), 1023-1029. Atlantis Press. http://doi.org/10.2991/ assehr.k.201209.162

30. Mârza, B., Mărcuță, A., \& Mărcuță, L. (2017). The impact of creative accounting on the preparing and 
presentation of financial statements. Revista Economică, 69(4), 129-136. Retrieved from https:// ideas.repec.org/a/blg/reveco/ v69y2017i4p129-136.html

31. Odo, J., \& Ugwu, I. J. (2020). Creative accounting and performance of deposit money banks in Niger1a. Journal of Accounting Information and Innovation, 6(8), 37-47. Retrieved from http:// eprints.gouni.edu.ng/2813/1/ John\%20Odo\%2C\%20Ph.D.\%20 and $\% 20 \mathrm{James} \% 20 \mathrm{Ike} \% 20$ Ugwu\%2C\%20Ph.D\%20\%281\%29. pdf

32. Ogoun, S., \& Atagboro, E. (2020). Internal audit and creative accounting practices in Ministries, Departments and Agencies (MDAS): An empirical analysis. Open Journal of Business and Management, 8(2), 552-568. https://doi. org/10.4236/ojbm.2020.82034

33. Okoye, E. I., \& Obioma, J. N. (2020). Impact of creative accounting techniques on firm financial performance: a study of selected firms in Nigeria. Journal of Accounting and Financial Management, 6(2), 1-14. Retrieved from https://iiardpub.org/get/ JAFM/VOL.\%206\%20NO.\%20 2\%202020/IMPACT\%20OF\%20 CREATIVE\%20ACCOUNTING. pdf

34. Panda, B., \& Leepsa, N. M. (2017). Agency theory: Review of Theory and Evidence on Problems and Perspectives. Indian Journal of Corporate Governance, 10(1), 74-95. https://doi. org/10.1177/0974686217701467

35. Park, N. K., \& Mezias, J. M. (2005). Before and after the technology sector crash: the effect of environmental munificence on stock market response to alliances of e-commerce firms. Strategic Management Journal, 26(11), 987 1007. Retrieved from https://doi. org/10.1002/smj.489

36. Qatawneh, A. M., \& Alqtish, A. M. (2017). Critical examination of the impact accounting ethics and creative accounting on the financial statements. International Business Research, 10(6), 104-111. https:// doi.org/10.5539/ibr.v10n6p104
37. Ramadan, Z. I. (2017). Creative accounting: theoretical framework for dealing with its determinants and institutional investors' involvement (Ph.D. Thesis). Cardiff Metropolitan University. Retrieved from https://repository.cardiffmet. ac.uk/handle/10369/9186

38. Ramaswami, A., Dreher, G. F., Bretz, R., \& Wiethoff, C. (2010). Gender, mentoring, and career success: The importance of organizational context. Personnel Psychology, 63(2), 385-405. https://doi.org/10.1111/j.17446570.2010.01174.x

39. Ross, S. (1973). The economic theory of agency: the principal's problem. American Economic Review, 63(2), 134-139. Retrieved from https://www.aeaweb.org/aer/ top20/63.2.134-139.pdf

40. Shawar, K. D., \& Qaisar, M. A. (2015). Creative accounting: developing a model. Research Journal of Recent Sciences, 4(11), 146-150. Retrieved from http://www.isca. in/rjrs/archive/v4/i11/20.ISCARJRS-2014-1150.pdf

41. Siyanbola, T. T., Benjamin, R. D., Amuda, M. B., \& Lloyd, J. F. (2020). Creative accounting and investment decision in listed manufacturing firms in Nigeria. Journal of Accounting and Taxation, 12(1), 39-47. https://doi.org/10.5897/ JAT2019.0373

42. Smith, H. J. (2003). The Shareholders vs. stakeholders' debate. MIT Sloan Management Review, 44(4), 85-90. Retrieved from https://sloanreview.mit.edu/ wp-content/uploads/2003/07/ b966946aae.pdf

43. Sorin, B., Ramona, R. P., \& Adrian, G. (2012). Qualitative study regarding the relationship between corporate governance and creative accounting. Annals of Faculty of Economics, 1(2), 642-647. Retrieved from https:// ideas.repec.org/a/ora/journl/ vly2012i2p642-647.html

44. Spence, M. (1973). Job market signaling. Quarterly Journal of Economics, 87(3), 355-374. Retrieved from https://viterbi-web. usc.edu/ shaddin/cs590fa13/papers/jobmarketsignaling.pdf
45. Susmuş, T., \& Demirhan, D. (2013). Creative accounting: a brief history and conceptual framework. Uluslararası Hakemli Sosyal Bilimler E-Dergisi, 38(2), 3-9. Retrieved from https:// arastirmax.com/tr/system/files/ dergiler/9383/makaleler/1/38/ arastrmx_9383_1_pp_1-20_6.pdf

46. Tamagno, L. G., Motta, V. E., M. Fernandes, M. A., Bizotto, S. L. B., \& Galelli, A. (2017). Creative accounting: A theoretical study. International Journal of Current Research, 9(10), 59041-59046. Retrieved from https://www. journalcra.com/sites/default/files/ issue-pdf/26459.pdf

47. Teitel, K., \& Machuga, S. (2009). Board characteristics and earnings quality: surrounding implication of a corporate governance code in Mexico. Journal of International Accounting, Auditing and Taxation, 18(1), 1-13. https:// doi.org/10.1016/j.intaccaud$\operatorname{tax} .2008 .12 .002$

48. Umobong, A., \& Ironkwe, U. (2017). Creative Accounting Practices and Financial Performance of Firms. International Journal of Innovative Finance and Economics Research, 5(1), 1-10.

49. Vladu, A. B., \& Matiş, D. (2010). Corporate governance and creative accounting: two concepts strongly connected? Some interesting insights highlighted by constructing the internal history of a literature. Annales Universitatis Apulensis Series Oeconomica Romania, 12(1), 332-346. Retrieved from http://oeconomica.uab.ro/ upload/lucrari/1220101/33.pdf 